Article

\title{
Eudesmane-Type Sesquiterpene Glycosides from Dictamnus dasycarpus Turcz.
}

\author{
Shengcai Yang ${ }^{1}$, Zheng Li ${ }^{1}$, Jianli Wang ${ }^{2}$, Jingya Ruan ${ }^{1}$, Chang Zheng ${ }^{2}$, Peijian Huang ${ }^{2}$, \\ Lifeng Han ${ }^{2}$, Yi Zhang ${ }^{1,2, *}$ and Tao Wang ${ }^{1,2, *}$ \\ 1 Tianjin State Key Laboratory of Modern Chinese Medicine, 312 Anshanxi Road, Nankai District, \\ Tianjin 300193, China; 15122473723@163.com (S.Y.); wo15510977612@163.com (Z.L.); \\ Ruanjy19930919@163.com (J.R.) \\ 2 Tianjin Key Laboratory of TCM Chemistry and Analysis, Institute of Traditional Chinese Medicine, \\ Tianjin University of Traditional Chinese Medicine, 312 Anshanxi Road, Nankai District, \\ Tianjin 300193, China; wj115802226160@126.com (J.W.); 18702270347@163.com (C.Z.); \\ hpjforever@sina.com (P.H.); hanlifeng_1@sohu.com (L.H.) \\ * Correspondence: zhwwxzh@263.net (Y.Z.); wangtao@tjutcm.edu.cn (T.W.); \\ Tel./Fax: +86-22-5959-6163(Y.Z.); +86-22-59596168 (T.W.)
}

Received: 2 February 2018; Accepted: 9 March 2018; Published: 13 March 2018

\begin{abstract}
Eudesmane-type sesquiterpenes have been reported to exhibit varieties of biological activities. During the process of investigating this kind of natural product from the root bark of Dictamnus dasycarpus Turcz., 13 eudesmane-type sesquiterpene glycosides including six new isolates, named as dictameudesmnosides $A_{1}(1), A_{2}(2), B(3), C(4), D(5)$, and $E(6)$, together with seven known ones (7-13), were obtained. Herein, their structures were determined by the analysis of physical data, spectroscopic analysis, and chemical methods. The existence of $\alpha$-configuration glucose units in their structures $(\mathbf{1 - 5 , 8 )}$ is not very common in natural glycosidic components. Meanwhile, compounds 3-5, 7, and 9-13 displayed TG accumulation inhibitory effects on HepG2 cells.
\end{abstract}

Keywords: Dictamnus dasycarpus Turcz.; sesquiterpene glycoside; eudesmane-type sesquiterpene; dictameudesmnoside; triglyceride accumulation; HepG2 cell

\section{Introduction}

Eudesmane-type sesquiterpenes and their glycosides, as one of the secondary metabolites, show broad bioactivities, including anti-inflammatory [1], anticancer [2,3], anti-angiogenic [4], antifungal [5], and anti-hepatitis B virus [6] activities, which make phytochemical or bioactive investigations into these kinds of constituents meaningful.

The root bark of Dictamnus dasycarpus Turcz., also known as Cortex Dictamni, belongs to the Rutaceae family. It is a plant rich in eudesmane-type sesquiterpenes [7,8]. As a traditional Chinese medicine, $D$. dasycarpus has been commonly used in the treatment of inflammation, microbial infection, pruritus vulvae, eczema, scabies, cancer, and other diseases in China for thousands of years because of its abilities to arrest itching, clear away heat, and eliminate dampness [9]. In addition, the decoction could effectively inhibit body weight and fat content increase caused by high fat diet, reduce triglyceride (TG) and total cholesterol contents in blood, and alleviate obesity [10].

During the process of investigating eudesmane-type sesquiterpenes from the root bark of D. dasycarpus, 13 compounds including six new isolates, named as dictameudesmnosides $A_{1}(\mathbf{1}), A_{2}(\mathbf{2})$, B (3), C (4), D (5), and E (6), together with seven known ones, dictamnosides B (7) [7], G (8) [11], C (9) [7], A (10) [7], L (11) [8], D (12) [7], and K (13) [8], were obtained. Meanwhile, in vitro bioactivity screening experiments testing the TG inhibitory effect for the 13 compounds were performed. We herein report the isolation and characterization of the abovementioned constituents along with their bioassay results. 


\section{Results and Discussion}

The 70\% ethanol-water extract from $D$. dasycarpus root bark was partitioned in an EtOAc- $\mathrm{H}_{2} \mathrm{O}$ mixture to afford EtOAc and $\mathrm{H}_{2} \mathrm{O}$ layer extract, respectively. The $\mathrm{H}_{2} \mathrm{O}$ layer extract was subjected to D101 macroporous resin column chromatography (CC) and eluted with $\mathrm{H}_{2} \mathrm{O}$ and $95 \% \mathrm{EtOH}$, successively. Then, 95\% EtOH eluted fraction was isolated by silica gel, Sephadex LH-20 CC, and preparative high-performance liquid chromatography (pHPLC) to yield compounds 1-13 (Figure 1).
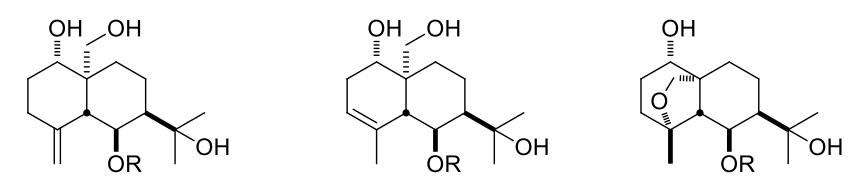

$$
\mathrm{R}: \begin{array}{cccc}
\mathbf{1} & \mathbf{2} & \mathbf{7} & \mathbf{8} \\
\hline \mathrm{S}_{2} & \mathrm{~S}_{3} & \mathrm{~S}_{1} & \mathrm{~S}_{4} \\
\hline
\end{array}
$$

$$
\mathrm{R}: \begin{array}{rr}
\mathbf{3} & \mathbf{9} \\
\hline \mathrm{S}_{4} & \mathrm{~S}_{1} \\
\hline
\end{array}
$$$$
\mathrm{R}: \begin{array}{ll}
4 & 10 \\
\hline S_{3} & S_{1} \\
\hline
\end{array}
$$
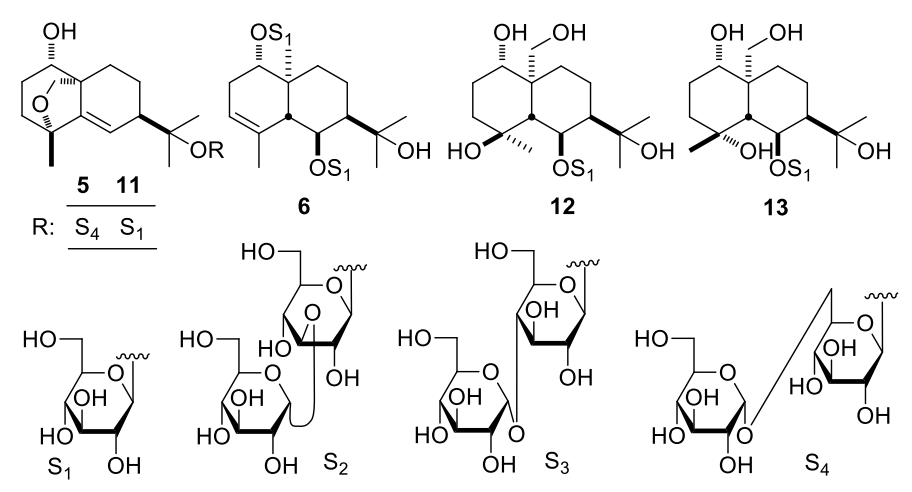

Figure 1. Compounds 1-13 obtained from D. dasycarpus.

Dictameudesmnoside $A_{1}(\mathbf{1})$ was isolated as white powder with positive optical rotation, $[\alpha]_{D}^{25}+53.5(\mathrm{MeOH})$. Its molecular formula was deduced to be $\mathrm{C}_{27} \mathrm{H}_{46} \mathrm{O}_{14}$ by the negative-ion HRESI-TOF-MS analysis $\left(\mathrm{m} / z 593.2826[\mathrm{M}-\mathrm{H}]^{-}\right.$; calcd for $\left.\mathrm{C}_{27} \mathrm{H}_{45} \mathrm{O}_{14}, 593.2815\right)$. Acid hydrolysis of $\mathbf{1}$ yielded D-glucose, which was identified by its retention time and optical rotation using chiral detection by HPLC analysis [12]. The ${ }^{1} \mathrm{H}$ and ${ }^{13} \mathrm{C}-\mathrm{NMR}$ (Table $1, \mathrm{CD}_{3} \mathrm{OD}$ ) spectra (Supplementary data) of $\mathbf{1}$, which were assigned by various $2 \mathrm{D}-\mathrm{NMR}$ experiments $\left({ }^{1} \mathrm{H}-{ }^{1} \mathrm{H}\right.$ COSY, HSQC, HMBC), showed signals assignable to one $\beta$-D-glucopyranosyl $\left(\delta 4.47\left(1 \mathrm{H}, \mathrm{d}, J=8.0 \mathrm{~Hz}, \mathrm{H}-1^{\prime}\right)\right)$, and one $\alpha$-D-glucopyranosyl $\left(\delta 5.12\left(1 \mathrm{H}, \mathrm{d}, J=3.5 \mathrm{~Hz}, \mathrm{H}-1^{\prime \prime}\right)\right)$. Twenty-seven carbon signals were displayed in its ${ }^{13} \mathrm{C}$-NMR spectrum. In addition to the carbon signals represented by $\beta$-D-glucopyranosyl and $\alpha$-D-glucopyranosyl, the other 15 signals indicated that the aglycon of $\mathbf{1}$ was an eudesmane-type sesquiterpene, consisting of two tertiary methyl groups $\left(\delta 1.31,1.33\right.$ (3H each, both $\left.\left.\mathrm{s}, \mathrm{H}_{3}-12,13\right)\right)$, one oxygenated methylene group $\left(\delta 3.45,3.88\left(1 \mathrm{H}\right.\right.$ each, both $\left.\left.\mathrm{d}, J=11.5 \mathrm{~Hz}, \mathrm{H}_{2}-14\right)\right)$, two oxygenated methine protons $(\delta 3.60(1 \mathrm{H}, \mathrm{m}$, overlapped, $\mathrm{H}-1), 4.51(1 \mathrm{H}, \mathrm{dd}, J=5.0,6.5 \mathrm{~Hz}, \mathrm{H}-6))$, together with one terminal olefinic moiety $(\delta 4.88$, 4.92 (1H each, both br. s, $\left.\mathrm{H}_{2}-15\right)$ ). The ${ }^{1} \mathrm{H}-{ }^{1} \mathrm{H}$ COSY spectrum of 1 suggested the presence of four partial structures written in bold lines, as shown in Figure 2. Its planar structure was determined based on the key HMBC correlations from the following proton and carbon pairs: $\delta_{\mathrm{H}} 3.60(\mathrm{H}-1)$ to $\delta_{\mathrm{C}} 51.8(\mathrm{C}-5) ; \delta_{\mathrm{H}} 1.75,1.94\left(\mathrm{H}_{2}-2\right)$ to $\delta_{\mathrm{C}} 43.5(\mathrm{C}-10) ; \delta_{\mathrm{H}} 2.22,2.33\left(\mathrm{H}_{2}-3\right)$ to $\delta_{\mathrm{C}} 51.8(\mathrm{C}-5) ; \delta_{\mathrm{H}} 1.62$, $1.83\left(\mathrm{H}_{2}-8\right), 4.51(\mathrm{H}-6)$ to $\delta_{\mathrm{C}} 43.5(\mathrm{C}-10) ; \delta_{\mathrm{H}} 1.31\left(\mathrm{H}_{3}-12\right)$ to $\delta_{\mathrm{C}} 28.7(\mathrm{C}-13), 46.7(\mathrm{C}-7), 74.3(\mathrm{C}-11)$; $\delta_{\mathrm{H}} 1.33\left(\mathrm{H}_{3}-13\right)$ to $\delta_{\mathrm{C}} 30.6(\mathrm{C}-12), 46.7(\mathrm{C}-7), 74.3(\mathrm{C}-11) ; \delta_{\mathrm{H}} 3.45,3.88\left(\mathrm{H}_{2}-14\right)$ to $\delta_{\mathrm{C}} 28.7(\mathrm{C}-9)$, $43.5(\mathrm{C}-10), 51.8(\mathrm{C}-5), 82.4(\mathrm{C}-1) ; \delta_{\mathrm{H}} 4.88,4.92\left(\mathrm{H}_{2}-15\right)$ to $\delta_{\mathrm{C}} 36.8(\mathrm{C}-3), 51.8(\mathrm{C}-5), 147.7(\mathrm{C}-4) ; \delta_{\mathrm{H}}$ $4.47\left(\mathrm{H}-1^{\prime}\right)$ to $\delta_{\mathrm{C}} 78.4(\mathrm{C}-6) ; \delta_{\mathrm{H}} 5.12\left(\mathrm{H}-1^{\prime \prime}\right)$ to $\delta_{\mathrm{C}} 88.0\left(\mathrm{C}-3^{\prime}\right)$, which were very similar to those of dictamnoside $\mathrm{B}$ (7) [7], except for the signals due to the sugar moiety. The relative configuration was further elucidated by the NOESY experiment, and NOE correlations between $\delta_{\mathrm{H}} 3.60(\mathrm{H}-1)$ 
and $\delta_{\mathrm{H}} 1.59(\mathrm{H} \beta-9), 2.22(\mathrm{H} \beta-3), 2.55(\mathrm{H}-5) ; \delta_{\mathrm{H}} 1.98(\mathrm{H}-7)$ and $\delta_{\mathrm{H}} 3.45(\mathrm{H}-14 \mathrm{a}), 4.51(\mathrm{H}-6) ; \delta_{\mathrm{H}} 1.31$ $\left(\mathrm{H}_{3}-12\right)$ and $\delta_{\mathrm{H}} 1.59(\mathrm{H} \beta-9), 2.55(\mathrm{H}-5)$ (Figure 3) were observed. Consequently, the structure of dictameudesmnoside $A_{1}(\mathbf{1})$ was formulated as $5 \beta, 7 \alpha(H), 10 \alpha$-eudesm-4(15)-ene-1 $\alpha, 6 \beta, 11,14$-tetraol 6-O- $\alpha$-D-glucopyranosyl $(1 \rightarrow 3)-\beta$-D-glucopyranoside.
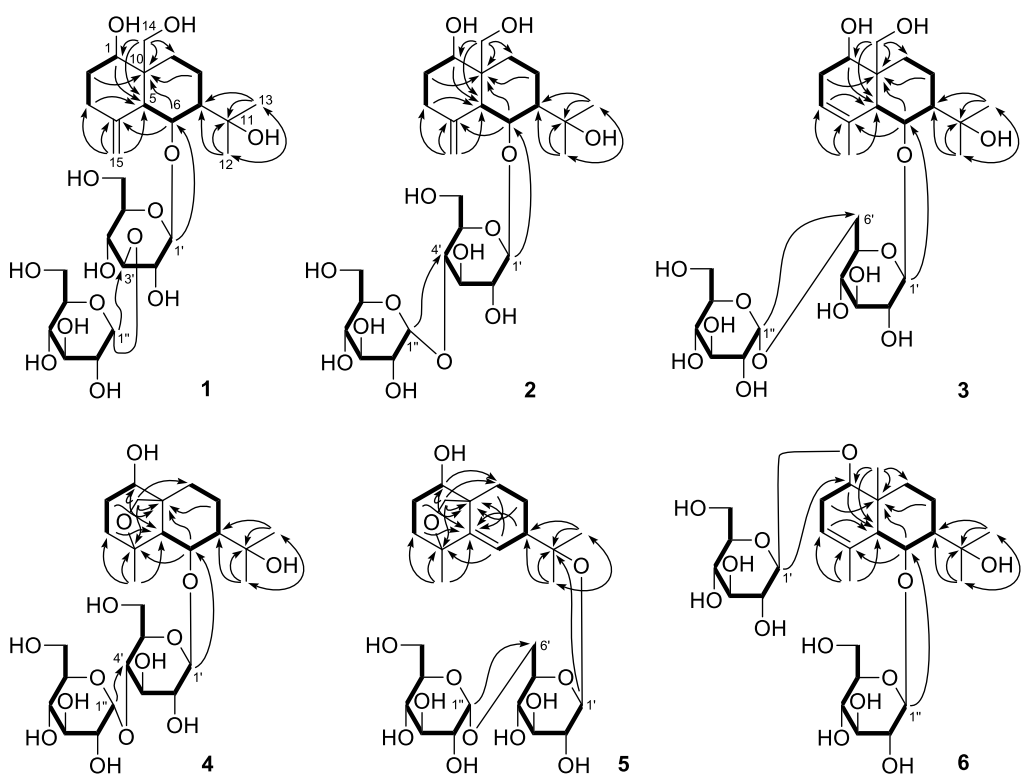

${ }^{1} \mathrm{H}^{1} \mathrm{H} \cos Y:-\mathrm{HMBC}: \frown$

Figure 2. The main ${ }^{1} \mathrm{H}-{ }^{1} \mathrm{H}$ COSY, and HMBC correlations of 1-6.

Table 1. ${ }^{1} \mathrm{H}$ and ${ }^{13} \mathrm{C}-\mathrm{NMR}$ data for $\mathbf{1}$ in $\mathrm{CD}_{3} \mathrm{OD}$ and $\mathrm{C}_{5} \mathrm{D}_{5} \mathrm{~N}$.

\begin{tabular}{|c|c|c|c|c|}
\hline \multirow{2}{*}{ No. } & \multicolumn{2}{|r|}{ In $\mathrm{CD}_{3} \mathrm{OD}$} & \multicolumn{2}{|c|}{ In $\mathrm{C}_{5} \mathrm{D}_{5} \mathrm{~N}$} \\
\hline & $\delta_{C}$ & $\delta_{\mathrm{H}}(J$ in $\mathrm{Hz})$ & $\delta_{C}$ & $\delta_{\mathrm{H}}(J$ in $\mathrm{Hz})$ \\
\hline 1 & 82.4 & $3.60(\mathrm{~m}$, overlapped $)$ & 81.5 & $3.65(\mathrm{dd}, 5.0,11.0)$ \\
\hline 2 & 33.9 & $1.75,1.94$ (both m) & 33.9 & $2.08(\mathrm{~m})$ \\
\hline 3 & 36.8 & $2.22,2.33$ (both m) & 36.3 & $2.35(\mathrm{~m})$ \\
\hline 4 & 147.7 & - & 147.3 & - \\
\hline 5 & 51.8 & $2.55(\mathrm{~d}, 6.5)$ & 51.2 & $2.78(\mathrm{~d}, 7.0)$ \\
\hline 6 & 78.4 & $4.51(\mathrm{dd}, 5.0,6.5)$ & 77.5 & $4.91(\mathrm{dd}, 5.5,6.5)$ \\
\hline 7 & 46.7 & $1.98(\mathrm{~m})$ & 46.2 & $2.32(\mathrm{~m})$ \\
\hline 8 & 20.3 & $1.62,1.83$ (both m) & 20.3 & $1.76,2.02$ (both m) \\
\hline 9 & 28.7 & $1.59,2.25$ (both m) & 28.9 & $1.89,2.78$ (both m) \\
\hline 10 & 43.5 & - & 43.1 & - \\
\hline 11 & 74.3 & - & 72.7 & - \\
\hline 12 & 30.6 & $1.31(\mathrm{~s})$ & 31.3 & $1.49(\mathrm{~s})$ \\
\hline 13 & 28.7 & $1.33(\mathrm{~s})$ & 28.5 & $1.53(\mathrm{~s})$ \\
\hline 14 & 64.4 & $3.45,3.88$ (both d, 11.5) & 63.9 & $3.82,4.31$ (both d, 11.0) \\
\hline 15 & 107.5 & $4.88,4.92$ (both br. s) & 106.7 & $4.97,5.08$ (both br. s) \\
\hline $1^{\prime}$ & 103.9 & $4.47(\mathrm{~d}, 8.0)$ & 103.8 & $4.98(\mathrm{~d}, 7.5)$ \\
\hline $2^{\prime}$ & 74.0 & $3.26(\mathrm{dd}, 9.0,9.0)$ & 73.5 & $3.88(\mathrm{dd}, 7.5,9.0)$ \\
\hline $3^{\prime}$ & 88.0 & $3.43(\mathrm{dd}, 9.0,9.0)$ & 88.2 & $4.11(\mathrm{dd}, 9.0,9.0)$ \\
\hline $4^{\prime}$ & 70.5 & $3.60(\mathrm{~m}$, overlapped $)$ & 70.4 & $4.36(\mathrm{dd}, 9.0,9.0)$ \\
\hline $5^{\prime}$ & 77.3 & $3.06(\mathrm{~m})$ & 77.5 & $3.57(\mathrm{~m})$ \\
\hline $6^{\prime}$ & 62.0 & $3.70(\mathrm{~m})$ & 61.8 & $4.27(\mathrm{~m})$ \\
\hline $1^{\prime \prime}$ & 101.5 & $5.12(\mathrm{~d}, 3.5)$ & 102.1 & $5.84(\mathrm{~d}, 4.0)$ \\
\hline $2^{\prime \prime}$ & 74.0 & $3.44(\mathrm{dd}, 3.5,9.0)$ & 74.3 & $4.17(\mathrm{dd}, 4.0,9.0)$ \\
\hline $3^{\prime \prime}$ & 75.1 & $3.65(\mathrm{dd}, 9.0,9.0)$ & 75.6 & $4.57(\mathrm{dd}, 9.0,9.0)$ \\
\hline $4^{\prime \prime}$ & 71.8 & $3.27(\mathrm{dd}, 9.0,9.0)$ & 72.0 & $4.18(\mathrm{dd}, 9.0,9.0)$ \\
\hline $5^{\prime \prime}$ & 74.2 & $3.87(\mathrm{~m})$ & 74.5 & $4.76(\mathrm{~m})$ \\
\hline \multirow[t]{2}{*}{$6^{\prime \prime}$} & 62.6 & $3.63(\mathrm{dd}, 4.0,12.0)$ & 62.5 & $4.29(\mathrm{dd}, 6.0,12.0)$ \\
\hline & & $3.82(\mathrm{dd}, 1.5,12.0)$ & & $4.47(\mathrm{dd}, 2.5,12.0)$ \\
\hline
\end{tabular}




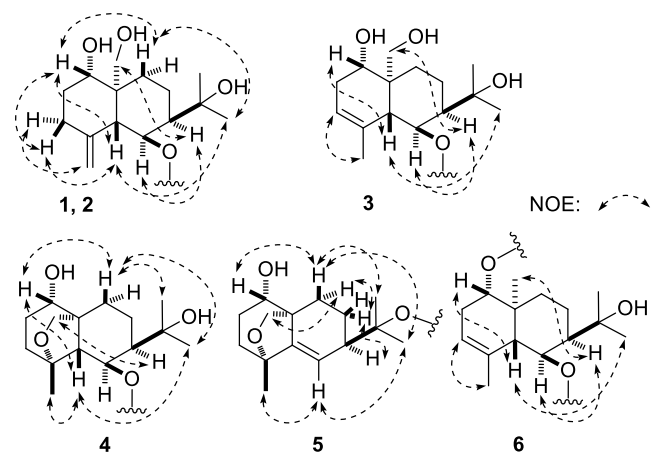

Figure 3. The main NOE correlations of the aglycons of 1-6.

Dictameudesmnoside $\mathrm{A}_{2}$ (2) was obtained as a white powder with positive optical rotation $\left([\alpha]_{D}^{25}+32.1, \mathrm{MeOH}\right)$. Its HRESI-TOF-MS showed the $[\mathrm{M}+\mathrm{COOH}]^{-}$ion peak at $\mathrm{m} / \mathrm{z} 639.2883$ (calcd for $\mathrm{C}_{28} \mathrm{H}_{47} \mathrm{O}_{16}, 639.2870$ ), consistent with the same molecular formula, $\mathrm{C}_{27} \mathrm{H}_{46} \mathrm{O}_{14}$, as that of 1 . The ${ }^{1} \mathrm{H}$ and ${ }^{13} \mathrm{C}$-NMR spectroscopic data comparison of $\mathbf{2}$ (Table 2, $\mathrm{CD}_{3} \mathrm{OD}$ ) with $\mathbf{1}$ revealed that both of them have the same aglycon, $5 \beta, 7 \alpha(H), 10 \alpha$-eudesm-4(15)-ene- $1 \alpha, 6 \beta, 11$,14-tetraol $(\delta 1.31,1.32$ (3H each, both s, $\left.\mathrm{H}_{3}-12,13\right), 3.44,3.87$ (1H each, both $\left.\mathrm{d}, J=12.0 \mathrm{~Hz}, \mathrm{H}_{2}-14\right), 3.62(1 \mathrm{H}, \mathrm{m}, \mathrm{H}-1), 4.50(1 \mathrm{H}, \mathrm{dd}, J=5.0,6.5 \mathrm{~Hz}$, $\mathrm{H}-6), 4.88,4.91$ (1H each, both br. $\left.\left.\mathrm{s}, \mathrm{H}_{2}-15\right)\right]$, one $\beta$-D-glucopyranosyl [ $\left.\delta 4.44\left(1 \mathrm{H}, \mathrm{d}, J=8.0 \mathrm{~Hz}, \mathrm{H}-1^{\prime}\right)\right]$, along with one $\alpha$-D-glucopyranosyl $\left[\delta 5.14\left(1 \mathrm{H}, \mathrm{d}, J=3.5 \mathrm{~Hz}, \mathrm{H}-1^{\prime \prime}\right)\right)$. Finally, the linkage positions of the abovementioned groups were determined by the long-range correlations observed from $\delta_{\mathrm{H}}$ $4.44\left(\mathrm{H}-1^{\prime}\right)$ to $\delta_{\mathrm{C}} 78.4(\mathrm{C}-6) ; \delta_{\mathrm{H}} 5.14\left(\mathrm{H}-1^{\prime \prime}\right)$ to $\delta_{\mathrm{C}} 80.8\left(\mathrm{C}-4^{\prime}\right)$ in the HMBC experiment. Furthermore, the NOE correlations between proton and proton pairs were similar to those of 1 . Then, the structure of dictameudesmnoside $A_{2}(2)$ was established as $5 \beta, 7 \alpha(H), 10 \alpha$-eudesm-4(15)-ene- $1 \alpha, 6 \beta, 11,14$-tetraol 6-O- $\alpha$-D-glucopyranosyl $(1 \rightarrow 4)-\beta$-D-glucopyranoside.

Table 2. ${ }^{1} \mathrm{H}$ and ${ }^{13} \mathrm{C}-\mathrm{NMR}$ data for 2 in $\mathrm{CD}_{3} \mathrm{OD}$ and $\mathrm{C}_{5} \mathrm{D}_{5} \mathrm{~N}$.

\begin{tabular}{|c|c|c|c|c|}
\hline \multirow{2}{*}{ No. } & \multicolumn{2}{|r|}{ In $\mathrm{CD}_{3} \mathrm{OD}$} & \multicolumn{2}{|r|}{ In $\mathrm{C}_{5} \mathrm{D}_{5} \mathrm{~N}$} \\
\hline & $\delta_{C}$ & $\delta_{\mathrm{H}}(J$ in $\mathrm{Hz})$ & $\delta_{C}$ & $\delta_{\mathrm{H}}(J$ in $\mathrm{Hz})$ \\
\hline 1 & 82.4 & $3.62(\mathrm{~m})$ & 81.6 & $3.62(\mathrm{~m})$ \\
\hline 2 & 33.9 & $1.74,1.94$ (both m) & 34.0 & $2.05(\mathrm{~m})$ \\
\hline 3 & 36.8 & $2.23,2.34$ (both $\mathrm{m}$ ) & 36.3 & $2.35(\mathrm{~m})$ \\
\hline 4 & 147.7 & - & 147.7 & - \\
\hline 5 & 51.9 & $2.55(\mathrm{~d}, 6.5)$ & 51.5 & $2.75(\mathrm{~d}, 7.0)$ \\
\hline 6 & 78.4 & $4.50(\mathrm{dd}, 5.0,6.5)$ & 78.0 & $4.92(\mathrm{~m}$, overlapped $)$ \\
\hline 7 & 46.7 & $1.98(\mathrm{~m})$ & 46.6 & $2.29(\mathrm{~m})$ \\
\hline 8 & 20.3 & $1.62,1.83$ (both m) & 20.2 & 1.77, 2.11 (both m) \\
\hline 9 & 28.8 & $1.61,2.25$ (both m) & 28.9 & 1.96, 2.79 (both m) \\
\hline 10 & 43.5 & - & 42.9 & - \\
\hline 11 & 74.3 & - & 72.6 & - \\
\hline 12 & 30.6 & $1.31(\mathrm{~s})$ & 31.3 & $1.54(\mathrm{~s})$ \\
\hline 13 & 28.6 & $1.32(\mathrm{~s})$ & 28.7 & $1.59(\mathrm{~s})$ \\
\hline 14 & 64.5 & $3.44,3.87$ (both d, 12.0) & 64.4 & $3.79,4.32$ (both $d, 11.0$ ) \\
\hline 15 & 107.5 & $4.88,4.91$ (both br. s) & 106.3 & $4.96,5.01$ (both br. s) \\
\hline $1^{\prime}$ & 104.1 & $4.44(\mathrm{~d}, 8.0)$ & 104.5 & $4.90(\mathrm{~d}, 8.0)$ \\
\hline $2^{\prime}$ & 74.8 & $3.17(\mathrm{dd}, 8.0,9.0)$ & 74.7 & $3.91(\mathrm{dd}, 8.0,8.5)$ \\
\hline $3^{\prime}$ & 78.3 & $3.55(\mathrm{dd}, 9.0,9.0)$ & 78.3 & 4.24 (m, overlapped) \\
\hline $4^{\prime}$ & 80.8 & $3.56(\mathrm{dd}, 9.0,9.0)$ & 80.7 & $4.41(\mathrm{dd}, 9.5,9.5)$ \\
\hline $5^{\prime}$ & 76.5 & $3.14(\mathrm{~m})$ & 76.5 & $3.49(\mathrm{~m})$ \\
\hline \multirow[t]{2}{*}{$6^{\prime}$} & 61.7 & $3.73(\mathrm{dd}, 2.0,12.0)$ & 61.4 & 4.23 ( $\mathrm{m}$, overlapped) \\
\hline & & $3.81(\mathrm{dd}, 4.5,12.0)$ & & $4.44(\mathrm{dd}, 2.5,12.0)$ \\
\hline $1^{\prime \prime}$ & 102.8 & $5.14(\mathrm{~d}, 3.5)$ & 103.0 & $5.91(\mathrm{~d}, 4.0)$ \\
\hline $2^{\prime \prime}$ & 74.2 & $3.43(\mathrm{dd}, 3.5,10.0)$ & 74.5 & $4.16(\mathrm{dd}, 4.0,9.0)$ \\
\hline $3^{\prime \prime}$ & 75.1 & $3.58(\mathrm{dd}, 9.0,9.0)$ & 75.5 & $4.59(\mathrm{dd}, 9.0,9.0)$ \\
\hline $4^{\prime \prime}$ & 71.6 & $3.24(\mathrm{dd}, 9.5,10.0)$ & 72.0 & $4.14(\mathrm{dd}, 9.0,9.0)$ \\
\hline $5^{\prime \prime}$ & 74.8 & $3.67(\mathrm{~m})$ & 75.3 & 4.56 (m, overlapped) \\
\hline \multirow{2}{*}{$6^{\prime \prime}$} & 62.9 & $3.64(\mathrm{dd}, 4.0,12.0)$ & 62.8 & $4.33(\mathrm{dd}, 7.0,12.0)$ \\
\hline & & 3.82 (br. d, ca. 12) & & 4.56 (m, overlapped) \\
\hline
\end{tabular}


Dictameudesmnoside B (3) was obtained as white power as well. On the basis of the HRESI-TOF-MS mass spectra, the molecular formula of 3 was deduced to be $\mathrm{C}_{27} \mathrm{H}_{46} \mathrm{O}_{14}(\mathrm{~m} / z 639.2886$ $[\mathrm{M}+\mathrm{COOH}]^{-}$; calcd for $\left.\mathrm{C}_{28} \mathrm{H}_{47} \mathrm{O}_{16}, 639.2870\right)$, the same as that of $\mathbf{1}$ and 2 . Its ${ }^{1} \mathrm{H}$ and ${ }^{13} \mathrm{C}-\mathrm{NMR}$ (Table 3, $\mathrm{CD}_{3} \mathrm{OD}$ ) spectra (Supplementary data) denoted that there were the same sugar moieties as the abovementioned two isolates: $\beta$-D-glucopyranosyl $\left(\delta 4.60\left(1 \mathrm{H}, \mathrm{d}, J=8.0 \mathrm{~Hz}, \mathrm{H}-1^{\prime}\right)\right)$, and $\alpha$-D-glucopyranosyl $\left(\delta 4.80\left(1 \mathrm{H}, \mathrm{d}, J=4.0 \mathrm{~Hz}, \mathrm{H}-1^{\prime \prime}\right)\right)$. Twenty-seven carbon signals similar to compounds 1 and 2 were displayed in its ${ }^{13} \mathrm{C}-\mathrm{NMR}$ spectrum. The abovementioned evidence indicated that 3 was the isomer of $\mathbf{1}$ and 2 . The ${ }^{1} \mathrm{H}$ and ${ }^{13} \mathrm{C}-\mathrm{NMR}$ spectra along with 2D-NMR, including ${ }^{1} \mathrm{H}_{-}{ }^{1} \mathrm{H}$ COSY, HSQC, and HMBC spectra, suggested three methyl $(\delta 1.30,1.33,1.83$ (3H each, all s, $\left.\left.\mathrm{H}_{3}-12,13,15\right)\right)$, one oxygenated methylene $(\delta[3.70(1 \mathrm{H}, \mathrm{m}$, overlapped $), 3.96(1 \mathrm{H}, \mathrm{d}, J=11.0 \mathrm{~Hz})]$, $\left.\mathrm{H}_{2}-14\right)$, two oxygenated methine $(\delta 3.76(1 \mathrm{H}, \mathrm{m}, \mathrm{H}-1), 4.49(1 \mathrm{H}, \mathrm{dd}, J=3.5,4.5 \mathrm{~Hz}, \mathrm{H}-6))$, together with one trisubstitued olefinic bond $(\delta 5.31(1 \mathrm{H}$, br. s, $\mathrm{H}-3))$ present in its aglycon. The existences of "-O-CH- $\mathrm{CH}_{2}-\mathrm{CH}=\mathrm{C}-$ " and " $-\mathrm{CH}-\mathrm{CH}(\mathrm{O})-\mathrm{CH}-\mathrm{CH}_{2}-\mathrm{CH}_{2}-{ }^{-}$" moieties were clarified by the correlations between proton and proton found in the ${ }^{1} \mathrm{H}-{ }^{1} \mathrm{H} \mathrm{COSY}$ spectrum. Meanwhile, the planar structure of its aglycon was determined by the long-range correlations observed from $\delta_{\mathrm{H}} 3.76(\mathrm{H}-1)$ to $\delta_{\mathrm{C}} 51.0(\mathrm{C}-5)$; $\delta_{\mathrm{H}} 2.12,2.52\left(\mathrm{H}_{2}-2\right)$ to $\delta_{\mathrm{C}} 42.7(\mathrm{C}-10) ; \delta_{\mathrm{H}} 5.31(\mathrm{H}-3)$ to $\delta_{\mathrm{C}} 51.0(\mathrm{C}-5) ; \delta_{\mathrm{H}} 1.83,2.00\left(\mathrm{H}_{2}-8\right), 4.49(\mathrm{H}-6)$ to $\delta_{\mathrm{C}} 42.7(\mathrm{C}-10) ; \delta_{\mathrm{H}} 1.30\left(\mathrm{H}_{3}-12\right)$ to $\delta_{\mathrm{C}} 30.4(\mathrm{C}-13), 45.3(\mathrm{C}-7), 74.2(\mathrm{C}-11) ; \delta_{\mathrm{H}} 1.33\left(\mathrm{H}_{3}-13\right)$ to $\delta_{\mathrm{C}} 29.8(\mathrm{C}-12)$, $45.3(\mathrm{C}-7), 74.2(\mathrm{C}-11) ; \delta_{\mathrm{H}} 3.70,3.96\left(\mathrm{H}_{2}-14\right)$ to $\delta_{\mathrm{C}} 26.6(\mathrm{C}-9), 42.7(\mathrm{C}-10), 51.0(\mathrm{C}-5), 79.6(\mathrm{C}-1) ; \delta_{\mathrm{H}} 1.83$ $\left(\mathrm{H}_{3}-15\right)$ to $\delta_{\mathrm{C}} 51.0(\mathrm{C}-5), 122.3(\mathrm{C}-3), 135.2$ (C-4) in its HMBC experiment, which was consistent with that of dictamnoside $\mathrm{C}$ (9) [7]. The relative configuration of $\mathbf{3}$ was elucidated according to the NOE correlations between $\delta_{\mathrm{H}} 2.92(\mathrm{H}-5)$ and $\delta_{\mathrm{H}} 1.30\left(\mathrm{H}_{3}-12\right), 3.76(\mathrm{H}-1) ; \delta_{\mathrm{H}} 1.97(\mathrm{H}-7)$ and $\delta_{\mathrm{H}} 3.70(\mathrm{H}-14 \mathrm{a})$, 4.49 (H-6) (Figure 3) displayed in the NOESY spectrum. Then, the aglycon of dictameudesmnoside $B$ (3) was elucidated to be $5 \beta, 7 \alpha(H), 10 \alpha$-eudesm-3-ene- $1 \alpha, 6 \beta, 11,14$-tetraol. Finally, the linkage positions of the sugar moieties were determined by the long-range correlations observed from $\delta_{\mathrm{H}} 4.60\left(\mathrm{H}-1^{\prime}\right)$ to $\delta_{\mathrm{C}} 79.4(\mathrm{C}-6) ; \delta_{\mathrm{H}} 4.80\left(\mathrm{H}-1^{\prime \prime}\right)$ to $\delta_{\mathrm{C}} 68.2\left(\mathrm{C}-6^{\prime}\right)$. On the basis of abovementioned evidence, the structure of dictameudesmnoside B (3) was deduced to be $5 \beta, 7 \alpha(H), 10 \alpha$-eudesm-3-ene- $1 \alpha, 6 \beta, 11,14$-tetraol 6-O- $\alpha$-D-glucopyranosyl $(1 \rightarrow 6)-\beta$-D-glucopyranoside.

Table 3. ${ }^{1} \mathrm{H}$ and ${ }^{13} \mathrm{C}$-NMR data for 3 in $\mathrm{CD}_{3} \mathrm{OD}$.

\begin{tabular}{|c|c|c|c|c|c|}
\hline No. & $\delta_{C}$ & $\delta_{H}(J$ in $\mathrm{Hz})$ & No. & $\delta_{C}$ & $\delta_{H}(J$ in $\mathbf{H z})$ \\
\hline 1 & 79.6 & $3.76(\mathrm{~m})$ & & & $3.96(\mathrm{~d}, 11.0)$ \\
\hline 2 & 35.0 & $2.12,2.52$ (both m) & 15 & 23.0 & $1.83(\mathrm{~s})$ \\
\hline 3 & 122.3 & 5.31 (br. s) & $1^{\prime}$ & 103.9 & $4.60(\mathrm{~d}, 8.0)$ \\
\hline 4 & 135.2 & - & $2^{\prime}$ & 75.2 & $3.20(\mathrm{dd}, 8.0,8.5)$ \\
\hline 5 & 51.0 & 2.92 (br. s) & $3^{\prime}$ & 78.3 & $3.36(\mathrm{~m}$, overlapped $)$ \\
\hline 6 & 79.4 & $4.49(\mathrm{dd}, 3.5,4.5)$ & $4^{\prime}$ & 71.6 & $3.33(\mathrm{dd}, 9.0,9.0)$ \\
\hline 7 & 45.3 & $1.97(\mathrm{~m})$ & $5^{\prime}$ & 76.5 & $3.36(\mathrm{~m}$, overlapped $)$ \\
\hline 8 & 18.8 & $\begin{array}{c}1.83(\mathrm{~m}, \text { overlapped }) \\
2.00(\mathrm{~m})\end{array}$ & $6^{\prime}$ & 68.2 & $\begin{array}{c}3.62(\mathrm{~m} \text {, overlapped }) \\
3.95(\mathrm{dd}, 4.5,12.0)\end{array}$ \\
\hline 9 & 26.6 & $\begin{array}{c}1.29 \text { (m, overlapped }) \\
2.34(\mathrm{ddd}, 1.5,8.0,13.5)\end{array}$ & $\begin{array}{l}1^{\prime \prime} \\
2^{\prime \prime}\end{array}$ & $\begin{array}{c}100.8 \\
73.8\end{array}$ & $\begin{array}{c}4.80(\mathrm{~d}, 4.0) \\
3.37(\mathrm{~m}, \text { overlapped })\end{array}$ \\
\hline 10 & 42.7 & - & $3^{\prime \prime}$ & 75.3 & $3.64(\mathrm{dd}, 9.5,9.5)$ \\
\hline 11 & 74.2 & - & $4^{\prime \prime}$ & 71.5 & $3.37(\mathrm{~m}$, overlapped $)$ \\
\hline 12 & 29.8 & $1.30(\mathrm{~s})$ & $5^{\prime \prime}$ & 73.6 & $3.61(\mathrm{~m})$ \\
\hline 13 & 30.4 & $1.33(\mathrm{~s})$ & $6^{\prime \prime}$ & 62.5 & $3.70(\mathrm{~m}$, overlapped $)$ \\
\hline 14 & 62.5 & $3.70(\mathrm{~m}$, overlapped $)$ & & & $3.78(\mathrm{dd}, 2.5,12.0)$ \\
\hline
\end{tabular}

Dictameudesmnoside C (4) was obtained as a white power. Its molecular formula was established as $\mathrm{C}_{27} \mathrm{H}_{46} \mathrm{O}_{14}$ based on the $[\mathrm{M}+\mathrm{COOH}]^{-}$quasi-molecular ion at $\mathrm{m} / \mathrm{z} 639.2878$ (calcd for $\mathrm{C}_{28} \mathrm{H}_{47} \mathrm{O}_{16}, 639.2870$ ) in the HRESI-TOF-MS spectrum. In addition to signals due to $\alpha$-D-glucopyranosyl $(1 \rightarrow 4)$ - $\beta$-D-glucopyranosyl $\left(\delta 5.05\left(1 \mathrm{H}, \mathrm{d}, J=8.0 \mathrm{~Hz}, \mathrm{H}-1^{\prime}\right), 5.84(1 \mathrm{H}, \mathrm{d}, J=3.5 \mathrm{~Hz}\right.$, $\left.\mathrm{H}-1^{\prime \prime}\right)$ ), like those of 2 , the ${ }^{1} \mathrm{H}$ and ${ }^{13} \mathrm{C}-\mathrm{NMR}$ (Table $4, \mathrm{C}_{5} \mathrm{D}_{5} \mathrm{~N}$ ) spectra (Supplementary data) of 
4 exhibited signals assignable to three methyl as well as four oxygenated carbons, including one methylene, two methine, and one quaternary carbon. However, no signal due to an olefinic bond presented in its ${ }^{13} \mathrm{C}-\mathrm{NMR}$ spectrum. Combined with the HRESI-TOF-MS experiment, the unsaturation degree for aglycon of 4 was three. Hence, three ring systems were deduced to exist in its aglycon. Comparing its ${ }^{13} \mathrm{C}-\mathrm{NMR}$ spectrum with that of 2 , the chemical shift of $\mathrm{C}-14$ shifted to a significantly lower field $\left(\delta_{C} 64.4\right.$ for $2 ; 70.4$ for 4 , in $\left.\mathrm{C}_{5} \mathrm{D}_{5} \mathrm{~N}\right)$. Moreover, the long-range correlation from $\delta_{\mathrm{H}} 3.93,4.42\left(\mathrm{H}_{2}-14\right)$ to $\delta_{\mathrm{C}} 83.4(\mathrm{C}-4)$ was found in the HMBC spectrum. According to the abovementioned two pieces of evidence, an ether bond had to be located at C-4 and C-14 in 4. Furthermore, its planar structure was identified by the proton and proton correlations and the long-range correlations from proton to carbon exhibited in the ${ }^{1} \mathrm{H}-{ }^{1} \mathrm{H}$ COSY and HMBC spectrum (Figure 2), respectively. The ${ }^{1} \mathrm{H}$ and ${ }^{13} \mathrm{C}-\mathrm{NMR}$ spectra of 4 were in accordance with those of dictamnoside A (10), whose configuration was determined by X-ray diffraction analysis [7]. Meanwhile, C-4 $4^{\prime}$ was substituted by an $\alpha$-D-glucopyranosyl group in 4 . Furthermore, NOE correlations were observed between the following proton and proton pairs: $\delta_{\mathrm{H}}$ $3.80(\mathrm{H}-1)$ and $\delta_{\mathrm{H}} 2.02(\mathrm{H} \beta-10), 2.59(\mathrm{H}-5) ; \delta_{\mathrm{H}} 2.59(\mathrm{H}-5)$ and $\delta_{\mathrm{H}} 1.42\left(\mathrm{H}_{3}-12\right), 1.66\left(\mathrm{H}_{3}-15\right) ; \delta_{\mathrm{H}}$ $2.04(\mathrm{H}-7)$ and $\delta_{\mathrm{H}} 4.42(\mathrm{H}-14 \mathrm{~b}) ; \delta_{\mathrm{H}} 2.02(\mathrm{H} \beta-10)$ and $\delta_{\mathrm{H}} 1.42\left(\mathrm{H}_{3}-12\right), 1.60\left(\mathrm{H}_{3}-13\right)$, as shown in Figure 3. Finally, its structure was identified as $4 \alpha, 10 \alpha$-epoxy- $5 \beta, 7 \alpha(H)$-eudesmane- $1 \alpha, 6 \beta, 11$-triol 6-O- $\alpha$-D-glucopyranosyl $(1 \rightarrow 4)-\beta$-D-glucopyranoside.

Table 4. ${ }^{1} \mathrm{H}$ and ${ }^{13} \mathrm{C}-\mathrm{NMR}$ data for 4 in $\mathrm{C}_{5} \mathrm{D}_{5} \mathrm{~N}$.

\begin{tabular}{cccccc}
\hline No. & $\delta_{\mathbf{C}}$ & $\boldsymbol{\delta}_{\mathbf{H}}(\boldsymbol{J}$ in Hz) & No. & $\boldsymbol{\delta}_{\mathbf{C}}$ & $\boldsymbol{\delta}_{\mathbf{H}}(\boldsymbol{J}$ in $\mathbf{H z})$ \\
\hline 1 & 76.1 & $3.80(\mathrm{~m})$ & 15 & 22.7 & $1.66(\mathrm{~s})$ \\
2 & 30.4 & $2.06(\mathrm{~m})$ & $1^{\prime}$ & 106.7 & $5.05(\mathrm{~d}, 8.0)$ \\
3 & 41.1 & $1.81,1.92($ both m) & $2^{\prime}$ & 74.5 & $3.97(\mathrm{dd}, 8.0,8.0)$ \\
4 & 83.4 & - & $3^{\prime}$ & 78.2 & $4.30(\mathrm{dd}, 8.0,8.0)$ \\
5 & 56.4 & 2.59 (br. s) & $4^{\prime}$ & 81.5 & $4.24(\mathrm{dd}, 9.0,9.0)$ \\
6 & 79.3 & $4.83($ br. s) & $5^{\prime}$ & 77.0 & $3.78(\mathrm{~m})$ \\
7 & 44.2 & $2.04(\mathrm{~m})$ & $6^{\prime}$ & 62.1 & $4.44(\mathrm{~m})$ \\
8 & 17.7 & $1.84,2.43($ both m) & $1^{\prime \prime}$ & 103.0 & $5.84(\mathrm{~d}, 3.5)$ \\
9 & 23.0 & $2.02,2.25($ both m) & $2^{\prime \prime}$ & 74.4 & $4.16(\mathrm{dd}, 3.5,9.5)$ \\
10 & 50.0 & - & $3^{\prime \prime}$ & 75.5 & $4.58(\mathrm{dd}, 9.5,9.5)$ \\
11 & 72.1 & - & $4^{\prime \prime}$ & 71.9 & $4.14(\mathrm{dd}, 9.5,9.5)$ \\
12 & 29.5 & $1.42(\mathrm{~s})$ & $5^{\prime \prime}$ & 75.3 & $4.55(\mathrm{~m})$ \\
13 & 30.6 & $1.60(\mathrm{~s})$ & $6^{\prime \prime}$ & 62.8 & $4.31(\mathrm{dd}, 6.0,12.0)$ \\
14 & 70.4 & $3.93,4.42($ both d, 8.5) & & & $4.54(\mathrm{dd}, 1.5,12.0)$ \\
\hline
\end{tabular}

Dictameudesmnoside D (5) was obtained as a white powder with positive optical rotation $\left([\alpha]_{D}^{25}+79.0\right)$. It was determined to possess the molecular formula $\mathrm{C}_{27} \mathrm{H}_{44} \mathrm{O}_{13}$ by its quasi-molecular ion peak at $m / z 621.2739[\mathrm{M}+\mathrm{COOH}]^{-}\left(\right.$calcd for $\left.\mathrm{C}_{28} \mathrm{H}_{45} \mathrm{O}_{15}, 621.2764\right)$ in the negative HRESI-TOF-MS experiment, which was 16 amu smaller than that of 4 . Meanwhile, comparing the ${ }^{1} \mathrm{H}$ and ${ }^{13} \mathrm{C}-\mathrm{NMR}$ (Table $5, \mathrm{CD}_{3} \mathrm{OD}$ ) spectra (Supplementary data) of 5 with those of 4 suggested that 5 had one tri-substituted olefinic group $(\delta 5.78(1 \mathrm{H}, \mathrm{d}, J=1.0 \mathrm{~Hz}, \mathrm{H}-6))$ more and one methylene as well as one oxygenated methine less than 4 . The olefinic bond should be located at C-5/C-6 in 4 from a biogenetic point of view, which was clarified by the long-range correlations from $\delta_{\mathrm{H}} 1.31\left(\mathrm{H}_{3}-15\right)$ to $\delta_{\mathrm{C}} 40.2(\mathrm{C}-3)$, $81.4(\mathrm{C}-4), 147.1(\mathrm{C}-5) ; \delta_{\mathrm{H}} 1.38,1.77\left(\mathrm{H}_{2}-8\right), 3.24,4.20\left(\mathrm{H}_{2}-14\right), 5.78(\mathrm{H}-6)$ to $\delta_{\mathrm{C}} 49.4(\mathrm{C}-10)$ observed in the HMBC experiment. Moreover, comparing the ${ }^{1} \mathrm{H}$ and ${ }^{13} \mathrm{C}-\mathrm{NMR}$ data with those of dictamnoside $\mathrm{L}(\mathbf{1 1})$, its aglycon was determined to be $4 \alpha, 10 \alpha$-epoxy- $5 \beta, 7 \alpha(H)$-eudesm-5-ene- $1 \alpha, 6 \beta, 11$-triol. Its relative configuration was clarified by the NOE correlations shown in the NOESY experiment (Figure 3). On the other hand, the ${ }^{1} \mathrm{H}$ and ${ }^{13} \mathrm{C}-\mathrm{NMR}$ signals due to the sugar moiety of 5 were in good agreement with those of 3 , which indicated that $\alpha$-D-glucopyranosyl $(1 \rightarrow 6)-\beta$-D-glucopyranosyl $\left(\delta 4.58\left(1 \mathrm{H}, \mathrm{d}, J=8.0 \mathrm{~Hz}, \mathrm{H}-1^{\prime}\right), 4.83\left(1 \mathrm{H}, \mathrm{d}, J=3.0 \mathrm{~Hz}, \mathrm{H}-1^{\prime \prime}\right)\right)$ should be present in 5 , too. Furthermore, the long-range correlation from $\delta_{\mathrm{H}} 4.58\left(\mathrm{H}-1^{\prime}\right)$ to $\delta_{\mathrm{C}} 81.7(\mathrm{C}-11)$ exhibited in the 
HMBC spectrum suggested that $\alpha$-D-glucopyranosyl $(1 \rightarrow 6)-\beta$-D-glucopyranosyl was attached to the $\mathrm{C}-11$ position of the aglycon. On the basis of the abovementioned evidence, the structure of dictameudesmnoside D (5) was formulated as $4 \alpha, 10 \alpha$-epoxy-5 $\beta, 7 \alpha(H)$-eudesm-5-ene-1 $\alpha, 6 \beta, 11$-triol 11-O- $\alpha$-D-glucopyranosyl $(1 \rightarrow 6)-\beta$-D-glucopyranoside.

Table 5. ${ }^{1} \mathrm{H}$ and ${ }^{13} \mathrm{C}-\mathrm{NMR}$ data for 5 in $\mathrm{CD}_{3} \mathrm{OD}$.

\begin{tabular}{|c|c|c|c|c|c|}
\hline No. & $\delta_{C}$ & $\delta_{H}(J$ in $\mathbf{H z})$ & No. & $\delta_{C}$ & $\delta_{\mathrm{H}}(J$ in $\mathrm{Hz})$ \\
\hline 1 & 72 & $3.78(\mathrm{~m})$ & 15 & 21.3 & $1.31(\mathrm{~s})$ \\
\hline 2 & 29.9 & $1.72,1.91$ (both m) & $1^{\prime}$ & 98.7 & $4.58(\mathrm{~d}, 8.0)$ \\
\hline 3 & 40.2 & $1.44,1.70$ (both m) & $2^{\prime}$ & 75.3 & $3.20(\mathrm{dd}, 8.0,8.0)$ \\
\hline 4 & 81.4 & - & $3^{\prime}$ & 78.4 & $3.39(\mathrm{dd}, 8.0,9.0)$ \\
\hline 5 & 147.1 & - & $4^{\prime}$ & 71.5 & $3.43(\mathrm{dd}, 9.0,9.0)$ \\
\hline 6 & 116.5 & $5.78(\mathrm{~d}, 1.0)$ & $5^{\prime}$ & 76.0 & $3.48(\mathrm{~m})$ \\
\hline 7 & 46.7 & $2.48(\mathrm{ddd}, 1.0,5.0,12.0)$ & $6^{\prime}$ & 67.5 & $3.62(\mathrm{dd}, 3.0,12.0)$ \\
\hline 8 & 21.7 & $1.38,1.77$ (both m) & & & $3.95(\mathrm{dd}, 4.5,12.0)$ \\
\hline \multirow[t]{2}{*}{9} & 26.3 & $\begin{array}{c}1.22 \text { (ddd, 3.0, 13.0 } \\
13.0)\end{array}$ & $1^{\prime \prime}$ & 100.0 & $4.83(\mathrm{~d}, 3.0)$ \\
\hline & & $2.19(\mathrm{ddd}, 2.0,2.0,13.0)$ & $2^{\prime \prime}$ & 73.8 & $3.36(\mathrm{dd}, 3.0,9.5)$ \\
\hline 10 & 49.4 & - & $3^{\prime \prime}$ & 75.3 & $3.64(\mathrm{~m}$, overlapped $)$ \\
\hline 11 & 81.7 & - & $4^{\prime \prime}$ & 71.7 & $3.33(\mathrm{dd}, 9.5,9.5)$ \\
\hline 12 & 25.6 & $1.30(\mathrm{~s})$ & $5^{\prime \prime}$ & 73.5 & 3.65 (m, overlapped) \\
\hline 13 & 22.6 & $1.17(\mathrm{~s})$ & $6^{\prime \prime}$ & 62.6 & $3.68(\mathrm{dd}, 5.5,12.0)$ \\
\hline 14 & 74.8 & $3.24,4.20$ (both d, 7.5) & & & $3.80(\mathrm{dd}, 2.0,12.0)$ \\
\hline
\end{tabular}

The molecular formula of dictameudesmnoside $\mathrm{E}(6)$ was assigned as $\mathrm{C}_{27} \mathrm{H}_{46} \mathrm{O}_{13}$ on the basis of the ${ }^{13} \mathrm{C}-\mathrm{NMR}$ data and negative-ion HRESI-TOF-MS $\left(\mathrm{m} / \mathrm{z} 623.2937[\mathrm{M}+\mathrm{COOH}]^{-}\right.$; calcd for $\mathrm{C}_{28} \mathrm{H}_{47} \mathrm{O}_{15}$, 623.2920) experiment, which was 16 amu less than that of 3 , suggesting that the difference between them was one oxygen atom on the elementary composition. The treatment of 6 with $1 \mathrm{M} \mathrm{HCl}$ liberated D-glucose, which was identified by HPLC analysis using an optical rotation detector [12]. The ${ }^{1} \mathrm{H}$ and ${ }^{13} \mathrm{C}-\mathrm{NMR}$ (Table 6, $\mathrm{CD}_{3} \mathrm{OD}$ ) spectra (Supplementary data) and various 2D-NMR $\left({ }^{1} \mathrm{H}-{ }^{1} \mathrm{H}\right.$ COSY, HSQC, HMBC) spectra indicated the presence of two $\beta$-D-glucopyranosyl groups $\left(\delta 4.31\left(1 \mathrm{H}, \mathrm{d}, J=7.5 \mathrm{~Hz}, \mathrm{H}-1^{\prime}\right), 4.54\left(1 \mathrm{H}, \mathrm{d}, J=8.0 \mathrm{~Hz}, \mathrm{H}-1^{\prime \prime}\right)\right)$. Meanwhile, its aglycon was similar to that of 3 . However, 6 had one methyl group more and one hydroxymethyl less than 3. In the HMBC experiment, long-range correlations were observed from the following proton and carbon pairs: $\delta_{\mathrm{H}} 3.65(\mathrm{H}-1)$ to $\delta_{\mathrm{C}} 53.8(\mathrm{C}-5) ; \delta_{\mathrm{H}} 2.05,2.51\left(\mathrm{H}_{2}-2\right)$ to $\delta_{\mathrm{C}} 39.2(\mathrm{C}-10) ; \delta_{\mathrm{H}} 5.29$ $(\mathrm{H}-3)$ to $\delta_{\mathrm{C}} 53.8(\mathrm{C}-5) ; \delta_{\mathrm{H}} 4.55(\mathrm{H}-6)$ to $\delta_{\mathrm{C}} 39.2(\mathrm{C}-10), 135.8(\mathrm{C}-4) ; \delta_{\mathrm{H}} 1.75,1.99\left(\mathrm{H}_{2}-8\right)$ to $\delta_{\mathrm{C}} 39.2$ $(\mathrm{C}-10) ; \delta_{\mathrm{H}} 1.24\left(\mathrm{H}_{3}-12\right)$ to $\delta_{\mathrm{C}} 30.2(\mathrm{C}-13), 45.0(\mathrm{C}-7), 73.9(\mathrm{C}-11) ; \delta_{\mathrm{H}} 1.33\left(\mathrm{H}_{3}-13\right)$ to $\delta_{\mathrm{C}} 29.5(\mathrm{C}-12)$, $45.0(\mathrm{C}-7), 73.9(\mathrm{C}-11) ; \delta_{\mathrm{H}} 0.93\left(\mathrm{H}_{3}-14\right)$ to $\delta_{\mathrm{C}} 30.6(\mathrm{C}-9), 39.2(\mathrm{C}-10), 53.8(\mathrm{C}-5), 87.5(\mathrm{C}-1) ; \delta_{\mathrm{H}} 1.82$ $\left(\mathrm{H}_{3}-15\right)$ to $\delta_{\mathrm{C}} 53.8(\mathrm{C}-5), 122.7(\mathrm{C}-3), 135.8(\mathrm{C}-4) ; \delta_{\mathrm{H}} 4.31\left(\mathrm{H}-1^{\prime}\right)$ to $\delta_{\mathrm{C}} 87.5(\mathrm{C}-1) ; \delta_{\mathrm{H}} 4.54\left(\mathrm{H}-1^{\prime \prime}\right)$ to $\delta_{C} 80.4$ (C-6). Then, the planar structure of dictameudesmnoside E (6) was deduced. Moreover, its relative configuration was elucidated by the NOE correlations between $\mathrm{H}-5$ and $\mathrm{H}-1, \mathrm{H}_{3}-12 ; \mathrm{H}-7$ and H-6, $\mathrm{H}_{3}-14$ observed in its NOESY experiment. Consequently, the structure of 6 was identified as $5 \beta, 7 \alpha(H), 10 \alpha$-eudesm-3-ene-1 $\alpha, 6 \beta, 11$-triol 1-O- $\beta$-D-glucopyranosyl-6-O- $\beta$-D-glucopyranoside.

The structures of known compounds 7-13 were identified by comparing their ${ }^{1} \mathrm{H}$ and ${ }^{13} \mathrm{C}-\mathrm{NMR}$ data with those of references.

In addition, TG accumulation inhibitory effects were screened by the sodium oleate (SO) induced hepatic cell line method [13]. As shown in Figure 4, compounds 3-5, 7, and 9-13 obtained from the $70 \%$ EtOH extract of $D$. dasycarpus root bark significantly inhibited TG accumulation in HepG2 cells. 
Table 6. ${ }^{1} \mathrm{H}$ and ${ }^{13} \mathrm{C}-\mathrm{NMR}$ data for 6 in $\mathrm{CD}_{3} \mathrm{OD}$ and $\mathrm{D}_{2} \mathrm{O}$.

\begin{tabular}{|c|c|c|c|c|}
\hline \multirow{2}{*}{ No. } & \multicolumn{2}{|r|}{ In $\mathrm{CD}_{3} \mathrm{OD}$} & \multicolumn{2}{|r|}{ In $\mathrm{D}_{2} \mathrm{O}$} \\
\hline & $\delta_{C}$ & $\delta_{H}(J$ in $\mathrm{Hz})$ & $\delta_{C}$ & $\delta_{H}(J$ in $\mathbf{H z})$ \\
\hline 1 & 87.5 & $3.65(\mathrm{~m}$, overlapped $)$ & 90.2 & $3.77(\mathrm{dd}, 7.5,11.5)$ \\
\hline 2 & 34.0 & $2.05,2.51$ (both m) & 35.1 & $2.07,2.50$ (both m) \\
\hline 3 & 122.7 & 5.29 (br. s) & 124.0 & 5.40 (br. s) \\
\hline 4 & 135.8 & - & 137.7 & - \\
\hline 5 & 53.8 & 2.89 (br. s) & 56.0 & 2.78 (br. s) \\
\hline 6 & 80.4 & $4.55(t, 4.0)$ & 83.4 & $4.66(t, 2.0)$ \\
\hline 7 & 45.0 & $1.85(\mathrm{~m})$ & 45.6 & $1.90(\mathrm{~m})$ \\
\hline 8 & 17.9 & $1.75,1.99$ (both m) & 18.2 & $1.85(\mathrm{~m})$ \\
\hline 9 & 30.6 & $1.30,2.18$ (both m) & 31.9 & $1.33,2.13$ (both m) \\
\hline 10 & 39.2 & - & 40.0 & - \\
\hline 11 & 73.9 & - & 76.6 & - \\
\hline 12 & 29.5 & $1.24(\mathrm{~s})$ & 30.3 & $1.24(\mathrm{~s})$ \\
\hline 13 & 30.2 & $1.33(\mathrm{~s})$ & 31.2 & $1.38(\mathrm{~s})$ \\
\hline 14 & 13.0 & $0.93(\mathrm{~s})$ & 15.0 & $0.91(\mathrm{~s})$ \\
\hline 15 & 22.9 & $1.82(\mathrm{~s})$ & 24.0 & $1.82(\mathrm{~s})$ \\
\hline $1^{\prime}$ & 106.0 & $4.31(\mathrm{~d}, 7.5)$ & 106.7 & $4.51(\mathrm{~d}, 8.0)$ \\
\hline $2^{\prime}$ & 75.7 & $3.15(\mathrm{dd}, 7.5,9.0)$ & 76.3 & $3.27(\mathrm{dd}, 8.0,8.5)$ \\
\hline $3^{\prime}$ & 78.2 & $3.35(\mathrm{~m}$, overlapped $)$ & 78.9 & $3.50(\mathrm{dd}, 8.5,9.0)$ \\
\hline $4^{\prime}$ & 71.8 & $3.26(\mathrm{dd}, 9.0,9.0)$ & 72.4 & $3.43(\mathrm{dd}, 9.0,9.0)$ \\
\hline $5^{\prime}$ & 77.8 & $3.24(\mathrm{~m}$, overlapped $)$ & 78.6 & 3.43 (m, overlapped) \\
\hline \multirow[t]{2}{*}{$6^{\prime}$} & 62.9 & $3.65(\mathrm{~m}$, overlapped $)$ & 63.4 & $3.72(\mathrm{dd}, 4.5,12.0)$ \\
\hline & & $3.85(\mathrm{dd}, 1.5,11.5)$ & & $3.82(\mathrm{dd}, 2.0,12.0)$ \\
\hline $1^{\prime \prime}$ & 105.4 & $4.54(\mathrm{~d}, 8.0)$ & 106.7 & $4.73(\mathrm{~d}, 8.0)$ \\
\hline $2^{\prime \prime}$ & 75.2 & $3.18(\mathrm{dd}, 8.0,9.0)$ & 76.5 & $3.27(\mathrm{dd}, 8.0,8.5)$ \\
\hline $3^{\prime \prime}$ & 78.5 & $3.35(\mathrm{~m}$, overlapped $)$ & 78.7 & $3.48(\mathrm{dd}, 8.5,9.0)$ \\
\hline $4^{\prime \prime}$ & 71.4 & $3.35(\mathrm{~m}$, overlapped $)$ & 72.7 & $3.36(\mathrm{dd}, 9.0,9.0)$ \\
\hline $5^{\prime \prime}$ & 77.8 & $3.22(\mathrm{~m}$, overlapped $)$ & 78.6 & 3.43 (m, overlapped) \\
\hline \multirow[t]{2}{*}{$6^{\prime \prime}$} & 62.6 & $3.70(\mathrm{dd}, 4.5,12.0)$ & 63.7 & $3.70(\mathrm{dd}, 6.0,12.0)$ \\
\hline & & $3.76(\mathrm{dd}, 2.0,12.0)$ & & $3.90(\mathrm{dd}, 2.0,12.0)$ \\
\hline
\end{tabular}

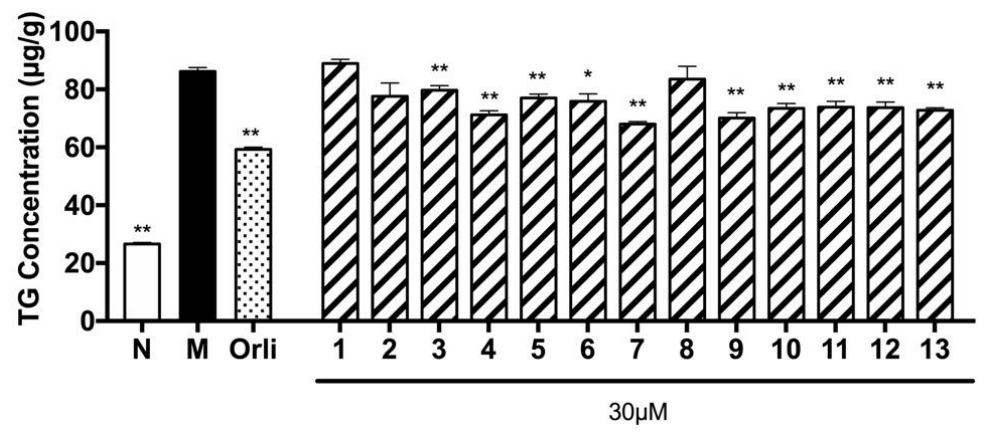

Figure 4. Effects of compounds 1-13 on TG overloading in HepG2 cells. Cells were treated with $200 \mu \mathrm{mol} / \mathrm{L}$ SO for $48 \mathrm{~h}$. Meanwhile, $30 \mu \mathrm{mol} / \mathrm{L}$ tested compounds or $5 \mu \mathrm{mol} / \mathrm{L}$ orlistat (Orli.) were co-incubated to evaluate their inhibitory effects, respectively. Each value represents the mean \pm S.E.M., $n=5,{ }^{* *} p<0.01,{ }^{*} p<0.05$ vs. model group (Mod.). Nor. = normal group.

\section{Experimental}

\subsection{General}

Optical rotations were measured on a Rudolph Autopol ${ }^{\circledR}$ IV automatic polarimeter $(l=50 \mathrm{~mm})$ (Rudolph Research Analytical, Hackettstown, NJ, USA). IR spectra were recorded on a Varian 640-IR FT-IR spectrophotometer (Varian Australia Pty Ltd., Mulgrave, Australia). NMR spectra were determined on a Bruker $500 \mathrm{MHz}$ NMR spectrometer (Bruker BioSpin AG Industriestrasse 26 
CH-8117, Fällanden, Switzerland) at $500 \mathrm{MHz}$ for ${ }^{1} \mathrm{H}$ and $125 \mathrm{MHz}$ for ${ }^{13} \mathrm{C}-\mathrm{NMR}$ (internal standard: TMS). Negative-ion mode HRESI-TOF-MS results were obtained on an Agilent Technologies 6520 Accurate-Mass Q-Tof LC/MS spectrometer (Agilent Corp., Santa Clara, CA, USA).

CC was performed on macroporous resin D101 (Haiguang Chemical Co., Ltd., Tianjin, China), silica gel (48-75 $\mu \mathrm{m}$, Qingdao Haiyang Chemical Co., Ltd., Qingdao, China), and ODS (40-63 $\mu \mathrm{m}$, YMC Co., Ltd., Tokyo, Japan). pHPLC columns, Cosmosil 5C 18 -MS-II (20 mm i.d. $\times 250 \mathrm{~mm}$, Nacalai Tesque, Inc., Kyoto, Japan), and Cosmosil PBr (20 mm i.d. $\times 250$ mm, Nacalai Tesque, Inc., Kyoto, Japan) were used to separate the constituents.

\subsection{Plant Material}

The root barks of Dictamnus dasycarpus Turcz. were purchased from the medicine market in Anguo city, Heibei province, China, and identified by Dr. Li Tianxiang (Experiment Teaching Department, Tianjin University of Traditional Chinese Medicine). The voucher specimen has been deposited at the Academy of Traditional Chinese Medicine of Tianjin University of TCM.

\subsection{Extraction and Isolation}

The root barks of $D$. dasycarpus $(9.0 \mathrm{~kg})$ were refluxed with $70 \%$ ethanol-water. Then, the $70 \%$ EtOH extract (1725.3 g) was partitioned in an EtOAc- $\mathrm{H}_{2} \mathrm{O}$ mixture $(1: 1, v / v)$. The $\mathrm{H}_{2} \mathrm{O}$ layer $(1253.8 \mathrm{~g})$ was subjected to D101 macroporous resin $\mathrm{CC}\left(\mathrm{H}_{2} \mathrm{O} \rightarrow 95 \% \mathrm{EtOH}\right)$. As a result, $\mathrm{H}_{2} \mathrm{O}(1032.9 \mathrm{~g})$ and 95\% EtOH (123.4 g) eluates were obtained. The $95 \% \mathrm{EtOH}$ eluate $(90.0 \mathrm{~g})$ was subjected to silica gel $\mathrm{CC}\left(\mathrm{CHCl}_{3} \rightarrow \mathrm{CHCl}_{3}-\mathrm{MeOH}(100: 1 \rightarrow 100: 3 \rightarrow 100: 7, v / v) \rightarrow \mathrm{CHCl}_{3}-\mathrm{MeOH}-\mathrm{H}_{2} \mathrm{O}(10: 3: 1 \rightarrow\right.$ 7:3:1 $\rightarrow$ $6: 4: 1, v / v / v$, lower layer) $\rightarrow \mathrm{MeOH})$, and 12 fractions (Fr. 1-Fr. 12) were given. Fraction $8(12.1 \mathrm{~g})$ was isolated by ODS CC (MeOH- $\left.\mathrm{H}_{2} \mathrm{O}(10 \% \rightarrow 20 \% \rightarrow 30 \% \rightarrow 40 \% \rightarrow 50 \% \rightarrow 60 \% \rightarrow 100 \%)\right)$ to yield seven fractions (Fr. 8-1-Fr. 8-7). Fraction 8-2 (4.4 g) was separated by pHPLC $\left(\mathrm{CH}_{3} \mathrm{CN}-\mathrm{H}_{2} \mathrm{O}(8: 92, v / v)\right.$ $+1 \%$ HAc, Cosmosil 5C18-MS-II column) to produce 11 fractions (Fr. 8-2-1-Fr. 8-2-11). Fraction 8-2-6 (575.1 mg) was further purified by pHPLC $\left(\mathrm{CH}_{3} \mathrm{CN}-\mathrm{H}_{2} \mathrm{O}(17: 83, v / v)\right.$, Cosmosil PBr column) to gain dictamnoside A (10, $69.4 \mathrm{mg})$. Fraction 8-2-9 $(379.3 \mathrm{mg})$ was isolated by pHPLC $\left(\mathrm{CH}_{3} \mathrm{CN}-\mathrm{H}_{2} \mathrm{O}\right.$ (17:83, v/v), Cosmosil PBr column) to yield dictamnoside B (7, $18.2 \mathrm{mg})$. Fraction 8-2-11 (923.2 mg) was separated by pHPLC $\left(\mathrm{CH}_{3} \mathrm{CN}-\mathrm{H}_{2} \mathrm{O}(17: 83, v / v)\right.$, Cosmosil $\mathrm{PBr}$ column), and dictamnoside $\mathrm{L}$ (11, $122.8 \mathrm{mg})$ was given. Fraction 8-4 $(1.01 \mathrm{~g})$ was purified by pHPLC $\left(\mathrm{CH}_{3} \mathrm{CN}-\mathrm{H}_{2} \mathrm{O}(20: 80, v / v)+1 \%\right.$ HAc, Cosmosil PBr column) to provide 18 fractions (Fr. 8-4-1-Fr. 8-4-18). Fraction 8-4-1 (233.2 mg) was further isolated by pHPLC $\left(\mathrm{CH}_{3} \mathrm{CN}-\mathrm{H}_{2} \mathrm{O}(16: 84, v / v)+1 \% \mathrm{HAc}\right.$, Cosmosil PBr column) to yield dictamnoside $\mathrm{C}(\mathbf{9}, 160.2 \mathrm{mg})$. Fraction $10(10.1 \mathrm{~g})$ was subjected to ODS CC $\left(\mathrm{MeOH}-\mathrm{H}_{2} \mathrm{O}(10 \% \rightarrow\right.$ $20 \% \rightarrow 30 \% \rightarrow 40 \% \rightarrow 50 \% \rightarrow 60 \% \rightarrow 80 \% \rightarrow 100 \%, v / v)$ ) to provide eight fractions (Fr. 10-1-Fr. 10-8). Fraction 10-2 (1.2 g) was separated by pHPLC (MeOH- $\mathrm{H}_{2} \mathrm{O}(20: 80, v / v)+1 \% \mathrm{HAc}$, Cosmosil 5C18-MS-II column), and then by pHPLC $\left(\mathrm{CH}_{3} \mathrm{CN}-\mathrm{H}_{2} \mathrm{O}(8: 92, v / v)\right.$, Cosmosil 5C18-MS-II column) to produce dictamnoside $\mathrm{D}(\mathbf{1 2}, 12.8 \mathrm{mg})$. Fraction $10-3(2.6 \mathrm{~g})$ was isolated by pHPLC $\left(\mathrm{CH}_{3} \mathrm{CN}-\mathrm{H}_{2} \mathrm{O}\right.$ $(9: 91, v / v)$, Cosmosil 5C18-MS-II column), and 16 fractions (Fr. 10-3-1-Fr. 10-3-16) were given. Fraction 10-3-4 was identified as dictamnoside $\mathrm{K}(\mathbf{1 3}, 88.0 \mathrm{mg})$. Fraction 10-3-6 (71.7 $\mathrm{mg})$ was purified by pHPLC $\left(\mathrm{CH}_{3} \mathrm{CN}-\mathrm{H}_{2} \mathrm{O}(11: 89, v / v)\right.$, Cosmosil PBr column) to obtain dictameudesmnoside $\mathrm{C}(4,17.4 \mathrm{mg})$. Using the same isolation condition, five fractions (Fr. 10-3-11-1-Fr. 10-3-11-5) were produced from fraction 10-3-11 (305.3 mg). Among them, fractions 10-3-11-1 and 10-3-11-5 were elucidated to be dictamnoside $\mathrm{G}(\mathbf{8}, 179.6 \mathrm{mg})$ and dictameudesmnoside B (3, $26.7 \mathrm{mg})$, respectively. Fraction 10-3-11-2 (20.6 mg) was subjected to silica gel CC $\left(\mathrm{CHCl}_{3}-\mathrm{MeOH}-\mathrm{H}_{2} \mathrm{O}(20: 3: 1 \rightarrow 15: 3: 1 \rightarrow 10: 3: 1, v / v / v\right.$, lower layer $\left.) \rightarrow \mathrm{MeOH}\right)$ to yield dictameudesmnoside $\mathrm{A}_{2}(2,20.6 \mathrm{mg})$. Fraction 10-3-13 (130.5 mg) was separated by pHPLC $\left(\mathrm{CH}_{3} \mathrm{CN}-\mathrm{H}_{2} \mathrm{O}(15: 85, v / v)\right.$, Cosmosil $\mathrm{PBr}$ column), and finally by silica gel $\left(\mathrm{CHCl}_{3}-\mathrm{MeOH}-\mathrm{H}_{2} \mathrm{O}(15: 3: 1\right.$ $\rightarrow$ 10:3:1, $v / v / v$, lower layer $) \rightarrow \mathrm{MeOH})$ to afford dictameudesmnoside $\mathrm{D}(5,38.7 \mathrm{mg})$. Fraction 10-3-14 (191.0 mg) was isolated by pHPLC $\left(\mathrm{CH}_{3} \mathrm{CN}-\mathrm{H}_{2} \mathrm{O}(15: 85, v / v)\right.$, Cosmosil PBr column) to yield seven fractions (Fr. 10-3-14-1-Fr. 10-3-14-7). Fraction 10-3-14-4 (30.0 mg) was further purified by silica gel CC $\left(\mathrm{CHCl}_{3}-\mathrm{MeOH}-\mathrm{H}_{2} \mathrm{O}(15: 3: 1 \rightarrow 10: 3: 1, v / v / v\right.$, lower layer $\left.) \rightarrow \mathrm{MeOH}\right)$ to give dictameudesmnoside $\mathrm{A}_{1}$ 
(1, $24.9 \mathrm{mg})$. Fraction 10-7 (2.2 g) was subjected to Sephadex LH-20 CC (MeOH), and two fractions (Fr. 10-7-1-Fr. 10-7-2) were given. Fraction 10-7-2 (1.41 g) was purified by pHPLC $\left(\mathrm{MeOH}-\mathrm{H}_{2} \mathrm{O}\right.$ $(45: 55, v / v)$, Cosmosil 5C18-MS-II column) to afford dictameudesmnoside E (6, $6.0 \mathrm{mg})$.

Dictameudesmnoside $A_{1}(\mathbf{1})$ : White powder; $[\alpha]_{D}^{25}+53.5(c=0.77, \mathrm{MeOH}) ; \mathrm{IR} v_{\max }(\mathrm{KBr}) \mathrm{cm}^{-1}: 3372$, 2931, 1650, 1601, 1455, 1380, 1150, 1075, 1037; ${ }^{1} \mathrm{H}-\mathrm{NMR}\left(500 \mathrm{MHz}, \mathrm{CD}_{3} \mathrm{OD} / \mathrm{C}_{5} \mathrm{D}_{5} \mathrm{~N}\right)$ and ${ }^{13} \mathrm{C}-\mathrm{NMR}$ $\left(125 \mathrm{MHz}, \mathrm{CD}_{3} \mathrm{OD} / \mathrm{C}_{5} \mathrm{D}_{5} \mathrm{~N}\right)$ spectroscopy data: see Table 1 . HRESI-TOF-MS: Negative-ion mode $\mathrm{m} / \mathrm{z}$ $593.2826[\mathrm{M}-\mathrm{H}]^{-}$(calcd for $\mathrm{C}_{27} \mathrm{H}_{45} \mathrm{O}_{14}, 593.2815$ ).

Dictameudesmnoside $A_{2}$ (2): White powder; $[\alpha]_{D}^{25}+32.1(c=0.86, \mathrm{MeOH}) ; \mathrm{IR} v_{\max }(\mathrm{KBr}) \mathrm{cm}^{-1}: 3381$, 2931, 1647, 1602, 1452, 1381, 1147, 1071, 1033; ${ }^{1} \mathrm{H}-\mathrm{NMR}\left(500 \mathrm{MHz}, \mathrm{CD}_{3} \mathrm{OD} / \mathrm{C}_{5} \mathrm{D}_{5} \mathrm{~N}\right)$ and ${ }^{13} \mathrm{C}-\mathrm{NMR}$ (125 MHz, CD ${ }_{3} \mathrm{OD} / \mathrm{C}_{5} \mathrm{D}_{5} \mathrm{~N}$ ) spectroscopy data: see Table 2. HRESI-TOF-MS: Negative-ion mode $\mathrm{m} / \mathrm{z}$ $639.2883[\mathrm{M}+\mathrm{COOH}]^{-}$(calcd for $\mathrm{C}_{28} \mathrm{H}_{47} \mathrm{O}_{16}, 639.2870$ ).

Dictameudesmnoside $B$ (3): White powder; $[\alpha]_{D}^{25}+23.6(c=0.66, \mathrm{MeOH}) ; \mathrm{IR} v_{\max }(\mathrm{KBr}) \mathrm{cm}^{-1}$ : 3394, 2925, 1636, 1604, 1451, 1371, 1152, 1075, 1035; ${ }^{1} \mathrm{H}-\mathrm{NMR}\left(500 \mathrm{MHz}, \mathrm{CD}_{3} \mathrm{OD}\right)$ and ${ }^{13} \mathrm{C}-\mathrm{NMR}$ $\left(125 \mathrm{MHz}, \mathrm{CD}_{3} \mathrm{OD}\right)$ spectroscopy data: see Table 3. HRESI-TOF-MS: Negative-ion mode $\mathrm{m} / \mathrm{z} 639.2886$ $[\mathrm{M}+\mathrm{COOH}]^{-}$(calcd for $\mathrm{C}_{28} \mathrm{H}_{47} \mathrm{O}_{16}, 639.2870$ ).

Dictameudesmnoside $C(4)$ : White powder; $[\alpha]_{D}^{25}+27.3(c=0.63, \mathrm{MeOH}) ; \mathrm{IR} v_{\max }(\mathrm{KBr}) \mathrm{cm}^{-1}: 3331$, 2934, 1455, 1383, 1150, 1073, 1027. ${ }^{1} \mathrm{H}-\mathrm{NMR}\left(500 \mathrm{MHz}, \mathrm{C}_{5} \mathrm{D}_{5} \mathrm{~N}\right)$ and ${ }^{13} \mathrm{C}-\mathrm{NMR}\left(125 \mathrm{MHz}, \mathrm{C}_{5} \mathrm{D}_{5} \mathrm{~N}\right)$

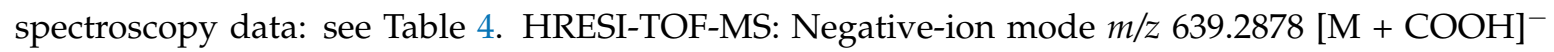
(calcd for $\mathrm{C}_{28} \mathrm{H}_{47} \mathrm{O}_{16}, 639.2870$ ).

Dictameudesmnoside $D(5)$ : White powder; $[\alpha]_{D}^{25}+79.0(c=0.82, \mathrm{MeOH}) ; \mathrm{IR} v_{\max }(\mathrm{KBr}) \mathrm{cm}^{-1}: 3385$, 2934, 2878, 1635, 1601, 1453, 1379, 1152, 1079, 1028; ${ }^{1} \mathrm{H}-\mathrm{NMR}\left(500 \mathrm{MHz}, \mathrm{CD}_{3} \mathrm{OD}\right)$ and ${ }^{13} \mathrm{C}-\mathrm{NMR}$ $\left(125 \mathrm{MHz}, \mathrm{CD}_{3} \mathrm{OD}\right)$ spectroscopy data: see Table 5. HRESI-TOF-MS: Negative-ion mode $\mathrm{m} / \mathrm{z} 621.2739$ $[\mathrm{M}+\mathrm{COOH}]^{-}$(calcd for $\left.\mathrm{C}_{28} \mathrm{H}_{45} \mathrm{O}_{15}, 621.2764\right)$.

Dictameudesmnoside $E$ (6): White powder; $[\alpha]_{D}^{25}-15.3(c=0.30, \mathrm{MeOH}) ; \mathrm{IR} v_{\max }(\mathrm{KBr}) \mathrm{cm}^{-1}$ : 3370, 2927, 1627, 1449, 1388, 1155, 1075, 1042, 1018; ${ }^{1} \mathrm{H}-\mathrm{NMR}\left(500 \mathrm{MHz}, \mathrm{CD}_{3} \mathrm{OD} / \mathrm{D}_{2} \mathrm{O}\right)$ and ${ }^{13} \mathrm{C}-\mathrm{NMR}$ (125 MHz, CD ${ }_{3} \mathrm{OD} / \mathrm{D}_{2} \mathrm{O}$ ) spectroscopy data: see Table 6; HRESI-TOF-MS: Negative-ion mode $\mathrm{m} / \mathrm{z}$ $623.2937[\mathrm{M}+\mathrm{COOH}]^{-}$(calcd for $\mathrm{C}_{28} \mathrm{H}_{47} \mathrm{O}_{15}, 623.2920$ ).

\subsection{Acid Hydrolysis of 1-6}

A solution of each of the new eudesmane-type sesquiterpene glycosides 1-6 (about $3.0 \mathrm{mg}$ ) in $1 \mathrm{M} \mathrm{HCl}(1 \mathrm{~mL})$ was heated under reflux for $3 \mathrm{~h}$, respectively. Then each reaction mixture was neutralized with Amberlite IRA-400 $\left(\mathrm{OH}^{-}\right.$form $)$and removed by filtration. The aqueous layer was subjected to HPLC analysis: HPLC column, Kaseisorb $\mathrm{LC} \mathrm{NH}_{2}-60-5,4.6 \mathrm{~mm}$ i.d. $\times 250 \mathrm{~mm}$ (Tokyo Kasei Co., Ltd., Tokyo, Japan); detection, optical rotation (Shodex OR-2 (Showa Denko Co., Ltd., Tokyo, Japan); mobile phase, $\mathrm{CH}_{3} \mathrm{CN}-\mathrm{H}_{2} \mathrm{O}((75: 25$, v/v; flow rate $1.0 \mathrm{~mL} / \mathrm{min}))$. From the results, instances D-glucose (12.8 min, positive optical rotation) for 1-6 were identified by comparison of their retention times and optical rotations with that of an authentic sample.

\subsection{Inhibitory Effects of Sodium Oleate-Induced Lipid Accumulation in HepG2 Cells}

Materials: HepG2 cell line was obtained from the Cell Resource Center of the Institute of Basic Medical Sciences, Chinese Academy of Medical Sciences and Peking Union Medical College (Beijing, China). Fetal Bovine Serum (FBS) was purchased from Biological Industries (Beit-Haemek, Israel). Dulbecco's modified Eagle's medium (DMEM), penicillin G sodium salt, and streptomycin sulfate were ordered from Thermo SCIENTIFIC (Waltham, MA, USA). TG assay kit was purchased from BioSino Bio-technology and Science Inc. (Beijing, China). SO and orlistat were obtained from Sigma-Aldrich Corporation (St. Louis, MO, USA). 
Cell culture: HepG2 cells were routinely cultured in DMEM-based medium as described before [13]. After cells reached about $80 \%$ confluence, seeded at a density of 80,000 cells $/ \mathrm{mL}$ in 48 -well plates for $24 \mathrm{~h}$, the experiments were performed.

Sodium oleate-induced lipid accumulation: To induce the overloading of intracellular lipid, SO was used as previous reported. Briefly, after being seeded in 48-well plates in FBS-free medium for $24 \mathrm{~h}$, HepG2 cells were exposed to $200 \mu \mathrm{M}$ SO in the presence or absence of isolates ( $30 \mu \mathrm{M})$ or the positive control, orlistat $(5 \mu \mathrm{M})$, for another $48 \mathrm{~h}$. The intracellular TG content was finally examined using a commercial assay kit at $492 \mathrm{~nm}$ after cells were rinsed with phosphate-buffered saline (PBS).

Statistical analysis: Values are expressed as means \pm S.D. All of the grouped data were statistically analyzed with SPSS 11.0. Significant differences between means were evaluated by one-way analysis of variance (ANOVA), and Tukey's Studentized range test was used for post hoc evaluations. $p<0.05$ was considered to indicate statistical significance.

\section{Conclusions}

In conclusion, 13 eudesmane-type sesquiterpene glycosides have been isolated from the $70 \%$ $\mathrm{EtOH}$ extract of $D$. dasycarpus root bark. Their structures have been determined on the basis of spectroscopic and chemical analyses. The existence of the $\alpha$-configuration glucose units in their structures (e.g., $\mathbf{1 - 5}, \mathbf{8}$ ) is not very common in natural glycosidic components.

On the other hand, as one of main constituents of $D$. dasycarpus root bark, the eudesmane-type sesquiterpene glycosides, isolates 3-5, 7, and 9-13, showed significant TG accumulation inhibitory activity, which was identical to the information reported by Kim et al. that the decoction could reduce TG and total cholesterol contents in blood as well as alleviate obesity effectively [10]. In addition, we can deduce that $D$. dasycarpus is one of potential active plants for improving metabolic disease.

Supplementary Materials: Supplementary materials are available on line.

Acknowledgments: Part of this research was supported by Programs for National Natural Science Foundation of China (81673703, 81673688).

Author Contributions: Yi Zhang and Tao Wang designed the research and wrote the manuscript; Shengcai Yang, Zheng Li, and Jianli Wang performed the experimental work; Chang Zheng and Peijian Huang were responsible for checking the spectra data; Jingya Ruan and Lifeng Han perfected the language. All authors discussed, edited, and approved the final version.

Conflicts of Interest: The authors declare no conflict of interest.

\section{References}

1. Jang, H.J.; Lee, S.; Lee, S.J.; Lim, H.J.; Jung, K.; Kim, Y.H.; Lee, S.W.; Rho, M.C. Anti-inflammatory activity of eudesmane-type sesquiterpenoids from Salvia plebeia. J. Nat. Prod. 2017, 80, 2666-2676. [CrossRef] [PubMed]

2. Tan, Z.; Zhao, J.; Liu, J.; Zhang, M.; Chen, R.; Xie, K.; Dai, J. Sesquiterpenoids from the cultured mycelia of Ganoderma capense. Fitoterapia 2017, 118, 73-79. [CrossRef] [PubMed]

3. Jeon, T.I.; Jung, C.H.; Cho, J.Y.; Park, D.K.; Moon, J.H. Identification of an anticancer compound against HT-29 cells from Phellinus linteus grown on germinated brown rice. Asian Pac. J. Trop. Biomed. 2013, 3, 785-789. [CrossRef]

4. $\quad$ Liang, N.; Li, Y.; Chung, H.Y. Two natural eudesmane-type sesquiterpenes from Laggera alata inhibit angiogenesis and suppress breast cancer cell migration through VEGF- and Angiopoietin 2-mediated signaling pathways. Int. J. Oncol. 2017, 51, 213-222. [CrossRef] [PubMed]

5. Alarif, W.M.; Al-Footy, K.O.; Zubair, M.S.; Halid Ph, M.; Ghandourah, M.A.; Basaif, S.A.; Al-Lihaibi, S.S.; Ayyad, S.E.; Badria, F.A. The role of new eudesmane-type sesquiterpenoid and known eudesmane derivatives from the red alga Laurencia obtusa as potential antifungal-antitumour agents. Nat. Prod. Res. 2016, 30, 1150-1155. [CrossRef] [PubMed] 
6. Xu, H.B.; Ma, Y.B.; Huang, X.Y.; Geng, C.A.; Wang, H.; Zhao, Y.; Yang, T.H.; Chen, X.L.; Yang, C.Y.; Zhang, X.M.; et al. Bioactivity-guided isolation of anti-hepatitis B virus active sesquiterpenoids from the traditional Chinese medicine: Rhizomes of Cyperus rotundus. J. Ethnopharmacol. 2015, 171, 131-140. [CrossRef] [PubMed]

7. Zhao, W.; Wolfender, J.; Hostettmann, K.; Li, H.; Stoeckli-Evans, H.; Xu, R.; Qin, G. Sesquiterpene glycosides from Dictamnus dasycarpus. Phytochemistry 1998, 47, 63-68. [CrossRef]

8. Chang, J.; Xuan, L.J.; Xu, Y.M.; Zhang, J.S. Seven new sesquiterpene glycosides from the root bark of Dictamnus dasycarpus. J. Nat. Prod. 2001, 64, 935-938. [CrossRef] [PubMed]

9. Yang, B.; Lee, H.B.; Kim, S.; Park, Y.C.; Kim, K.; Kim, H. Decoction of Dictamnus dasycarpus Turcz. root bark ameliorates skin lesions and inhibits inflammatory reactions in mice with contact dermatitis. Pharmacogn. Mag. 2017, 13, 483-487. [PubMed]

10. Kim, H.G.; Yoon, T.S.; Sung, Y.Y.; Jang, J.Y.; Jeon, M.S.; Chun, J.M. Dictamnus dasycarpus Cortex Extracts for Preventing and Treating Lipid-Related Cardiovascular Disease or Obesity. K.P. Patent 2,011,097,220 A 20,110,831, 31 August 2011.

11. Hu, H.; Jian, Y.; Zheng, X.; Cao, H. Three sesquiterpene glycosides from Elsholtzia bodinieri. Bull. Korean Chem. Soc. 2007, 28, 467-470. [CrossRef]

12. Zhang, Y.; Jin, L.; Chen, Q.; Wu, Z.; Dong, Y.; Han, L.; Wang, T. Hypoglycemic activity evaluation and chemical study on hollyhock flowers. Fitoterapia 2015, 102, 7-14. [CrossRef] [PubMed]

13. Wang, S.; Shi, P.; Qu, L.; Ruan, J.; Yang, S.; Yu, H.; Zhang, Y.; Wang, T. Bioactive constituents obtained from the seeds of Lepidium apetalum Willd. Molecules 2017, 22, 540. [CrossRef] [PubMed]

Sample Availability: Samples of all the compounds are available from the authors.

(c) 2018 by the authors. Licensee MDPI, Basel, Switzerland. This article is an open access article distributed under the terms and conditions of the Creative Commons Attribution (CC BY) license (http://creativecommons.org/licenses/by/4.0/). 